\title{
A new de novo mutation (A113T) in HMG box of the SRY gene leads to XY gonadal dysgenesis
}

Yi-tao Zeng, Zhao-rui Ren, Mei-lan Zhang, Ying Huang, Fan-yi Zeng, Shu-zhen Huang

\begin{abstract}
We describe a new point mutation in the SRY gene of a Chinese XY female with gonadal dysgenesis (Swyer syndrome). Using the double stranded DNA cycle sequencing method, a single nucleotide substitution of $G \rightarrow A$ was identified at codon 113 of the patient's SRY gene, resulting in a conservative amino acid change from alanine $(A)$ to threonine $(T)$ at a residue that lies within the putative DNA binding motif. With this mutation, one MnlI recognition site is abolished and a new BsmAI site is present in the DNA sequence of the SRY gene; therefore, it is easily detected by analysis of the digestion of the amplified SRY DNA fragment on an electrophoretic agarose gel. In situ hybridisation to the XY female's chromosomes showed that her mutant SRY gene was indeed located on the short arm of her $Y$ chromosome. The SRY mutation in the XY female reported here occurred de novo, as sequence analysis showed that it was not present in her father or other family members.

(f Med Genet 1993;30:655-7)
\end{abstract}

The development of a eutherian mammal as a male is the consequence of testis formation in the embryo, which is thought to be initiated by a gene on the $\mathrm{Y}$ chromosome, known as TDF (testis determining factor) in humans. ${ }^{12}$ Recently, this gene has been found to be close to the pseudoautosomal boundary of the $\mathrm{Y}$ chromosome and has been termed SRY, for sex determining region of the Y.3.-5 SRY encodes a small protein with homology to a conserved DNA binding motif known as the HMG (high mobility group) box. Direct genetic evidence for SRY being the TDF was obtained from the analysis of de novo mutations of SRY in XY females with gonadal dysgenesis. ${ }^{67}$ Further evidence derives from experiments with XX mice, transgenic for mouse Sry, leading to testicular development and a subsequent male phenotype. ${ }^{8}$

In this article, we describe a new point mutation in the HMG box motif of SRY in a Chinese XY female with gonadal dysgenesis (Swyer syndrome). This mutation resulted in a conservative amino acid change from alanine to threonine at a residue that lies within the putative DNA binding motif. This mutation was not present in the patient's father, sister, or uncle. Thus, the mutation occurred de novo. The results strongly suggest that this de novo mutation in the SRY gene was associated with sex inversion in the $\mathrm{XY}$ female.

\section{Materials and methods} CASE REPORT

The XY female patient was referred to Shanghai Institute of Medical Genetics at the age of 19 with primary amenorrhoea owing to hypergonadotrophic hypogonadism and absence of secondary sexual characteristics. She was $170 \mathrm{~cm}$ in height (taller than the mean height of Chinese females) and her external genitalia were those of a normal female. Cytogenetic analysis of peripheral lymphocytes showed a 46,XY karyotype with no evidence of mosaicism. C banding confirmed a Y chromosome. Endocrinological studies showed: FSH $>80 \mathrm{mIU} / \mathrm{ml}$, LH $37.3 \mathrm{mIU} / \mathrm{ml}$, PRL $15.5 \mathrm{ng} / \mathrm{ml}, \mathrm{E} 2<20 \mathrm{pg} / \mathrm{ml}$, testosterone $0.37 \mathrm{ng} / \mathrm{ml}, \mathrm{T} 31.1 \mathrm{ng} / \mathrm{ml}, \mathrm{T} 412.9 \mathrm{ng} / \mathrm{ml}$. Streak gonads and an aplastic uterus were diagnosed at laparotomy. Histological examination of the right streak gonad disclosed gonadoblastoma. The patient was diagnosed as having XY gonadal dysgenesis (Swyer syndrome).

Her parents were healthy and unrelated with normal karyotypes. She had a healthy 13 year old sister. Paternity in the family was confirmed by RBC antigen and HLA typing.

\section{METHOD}

Genomic DNA was extracted from the leucocytes of the XY female, her parents and sister, as well as 10 normal male and female controls. Referring to the nucleotide sequence of the human SRY gene, two sets of primers, named A, B and C, D were designed within the SRY open reading frame, amplifying $217 \mathrm{bp}$ and $226 \mathrm{bp}$ fragments, respectively. The primer sequences are: A: 5'-CCATGAACGCATTCATCGTGTG-3', B: 5'-GCCTTCCGACGAGGTCGATACT-3', C: 5'-GAGATCAGCAAGTAGCTGGGA-3', D: 5'-ACAACCTGTTGTCCAGTTGC-3', which were synthesised in an Applied Biosystems DNA synthesiser. The modification of DNA amplification by PCR with Taq DNA polymerase (Boehringer Mannheim) was performed according to a method described elsewhere. ${ }^{910}$

The PCR products of the XY female, her father, and normal males were subjected to direct sequencing of the SRY DNA sequence using a double strand (ds) DNA cycle sequencing method $^{11}$ according to the protocol recommended by BRL Life Technologies Inc. In brief, 1 pmol of the sequencing primer $\left(5^{\prime}\right.$-CCATGAACGCATTCA-TCGTGTG-3') was end labelled with $\mathrm{r}-{ }^{32} \mathrm{P}$ ATP $(>5000 \mathrm{Ci} / \mathrm{mmol}$, ICN) by $1 \mathrm{U}$ of $\mathrm{T} 4$ polynucleotide kinase (BRL) at $37^{\circ} \mathrm{C}$ for 30 minutes and then at $55^{\circ} \mathrm{C}$ for five minutes to stop the reaction. Then Received 26 October 1992 17 February 1993. 
$50 \mathrm{fmol}$ of template DNA were prereacted with $1 \mathrm{pmol}$ of labelled primer, $4.5 \mu \mathrm{l}$ of $10 \times$ sequencing buffer (Tris- $\mathrm{HCl}, \mathrm{pH} 9.0,300 \mathrm{mmol} / \mathrm{l}$, $\mathrm{MgCl}_{2}, 50 \mathrm{mmol} / \mathrm{l}, \mathrm{KCl} 300 \mathrm{mmol} / \mathrm{l}, \mathrm{W}-1$ $0.5 \%$ ), and $2.5 \mathrm{U}$ of $\mathrm{Taq}$ DNA polymerase (Cetus). The total volume of the prereaction mixture was adjusted to $36 \mu \mathrm{l}$ with distilled water and $8 \mu \mathrm{l}$ of the above prereaction mixture was individually distributed into four $0.5 \mathrm{ml}$ Eppendorf tubes containing ddNTP termination mixes and covered with $10 \mu \mathrm{l}$ of mineral oil. Thirty PCR cycles were then performed in a Perkin-Elmer Cetus DNA Thermal Cycler: denaturing at $90^{\circ} \mathrm{C}$ for one minute, annealing at $55^{\circ} \mathrm{C}$ for one minute, and extending at $70^{\circ} \mathrm{C}$ for two minutes. The reaction tubes were carefully removed from the incubation chamber and the reactions terminated by adding $5 \mu l$ of stop solution $(95 \% \mathrm{v} / \mathrm{v})$ formamide, $10 \mathrm{mmol} / 1$ EDTA ( $\mathrm{pH} 8.0), 0.1 \%(\mathrm{w} / \mathrm{v})$ bromophenol blue, $0.1 \%(\mathrm{w} / \mathrm{v})$ xylene cyanol to each tube. The reaction tubes were heated at $90^{\circ} \mathrm{C}$ for five minutes and then subjected to $8 \%$ polyacrylamide/TEB-urea gel electrophoresis at $27 \mathrm{~mA}$ for three hours. Autoradiography of the dried gels was performed for 24 hours at room temperature without an intensifying screen.

For further confirmation of the specific mutation in the SRY DNA sequence, $15 \mu$ l of the amplified SRY DNA fragments from the XY female, her father, and normal males were digested with restriction endonuclease $M n l \mathrm{I}$ or BsmAI (New England Biolabs) according to the manufacturer's recommendation.

\section{Results}

SRY sequences were amplified by PCR from DNA of the XY female, her father, and normal
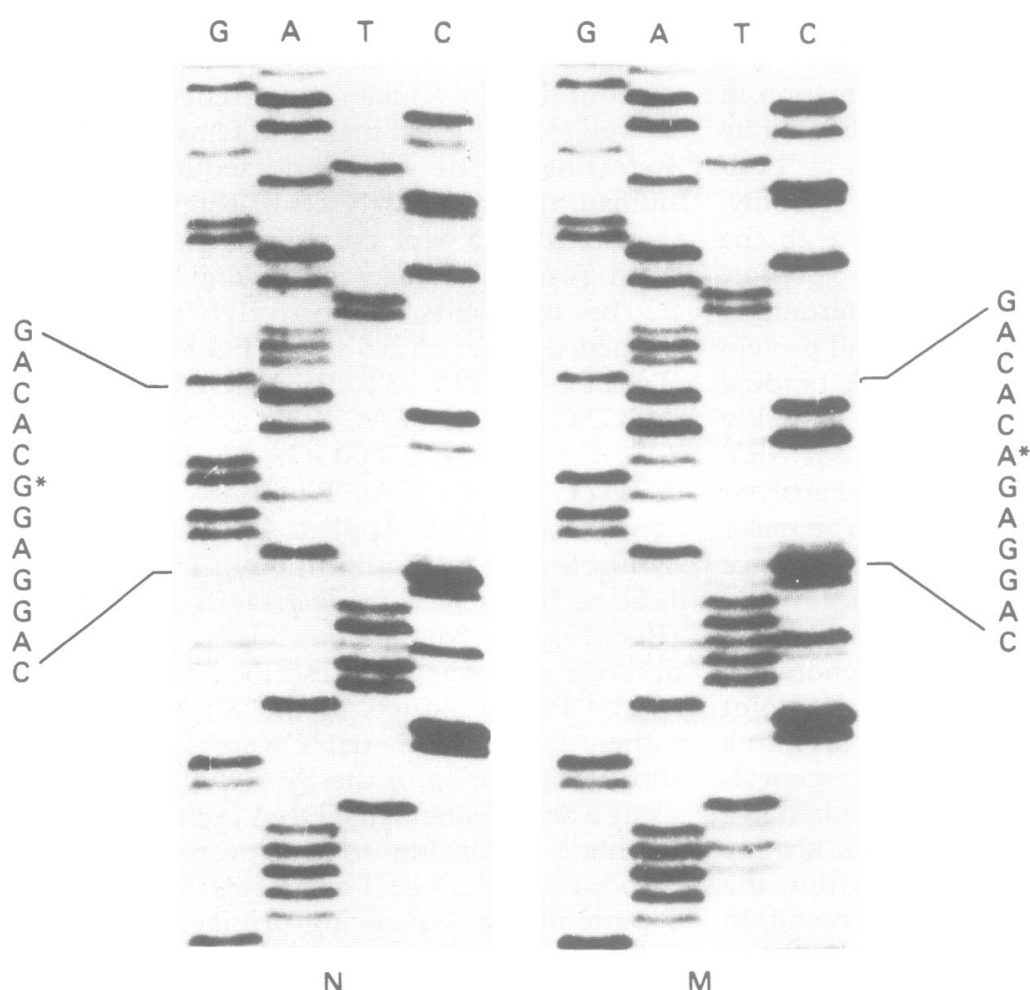

Figure 1 Sequence analysis of human SRY gene using double strand DNA cycle sequencing method. The section involving the mutation in the sequence from the $X Y$ female's mutant allele $(M)$ is compared with the corresponding section in the sequence from the normal allele $(N) .{ }^{*}$ indicates the mutant site. male controls. Specific amplified DNA bands of $217 \mathrm{bp}$ or $226 \mathrm{bp}$ were shown on the electrophoretic gels when using primer $\mathrm{A}+\mathrm{B}$ or $\mathrm{C}+\mathrm{D}$, respectively, while samples from the mother, sister, and normal female controls showed no corresponding amplified fragment. Direct sequence analysis of the SRY HMG box motif of the patient showed that a single nucleotide substitution of $\mathrm{G} \rightarrow \mathrm{A}$ had occurred at position $n t 747$ of the SRY gene in the XY female (fig 1), resulting in a conservative amino acid change from alanine (A) to threonine ( $\mathrm{T}$ ) at codon 113 (A113T), a residue that lies within the HMG box motif. This is a new, previously undescribed SRY mutation, which occurred de novo, as sequence analysis showed that it was not shared by her father or other family members.

While the A113T mutation, one $M n l \mathrm{I}$ recognition site was abolished and a new BsmAI site was present in the mutant SRY DNA sequence. The results of $M n l \mathrm{I}$ and BsmAI mapping of the amplified DNA are shown in fig 2 and fig 3, respectively. In situ hybridisation to the $X Y$ female's chromosomes indicated that her SRY gene was located on the short arm of the $Y$ chromosome (data not shown).

\section{Discussion}

The initiation of human male or female sexual development depends on the presence or absence of the $Y$ chromosome, ${ }^{1213}$ more specifically on a gene on the short arm of the $Y$ chromosome encoding a testis determining factor (TDF). By exploring detailed maps of

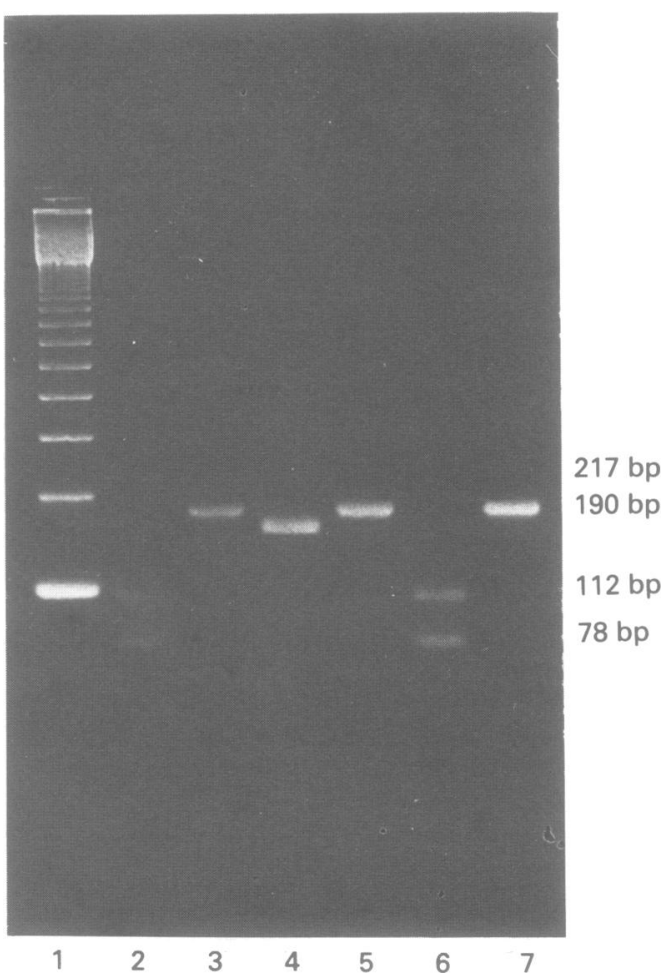

Figure 2 Analysis of the amplified SRY DNA fragments digested with MnlI on electrophoretic agarose gel. (1) $123 \mathrm{bp}$ DNA ladder marker, (2) father, after MnlI digestion $(112+78+27 \mathrm{bp})$, (3) father, without MnlI digestion (217 bp), (4) patient, after MnlI digestion $(190+27 \mathrm{bp}),(5)$ patient, without MnlI digestion (217 bp), (6) normal male, after MnlI digestion $(112+78+27 \mathrm{bp}),(7)$ normal male, without MnlI digestion ( $217 \mathrm{bp}$ ). 


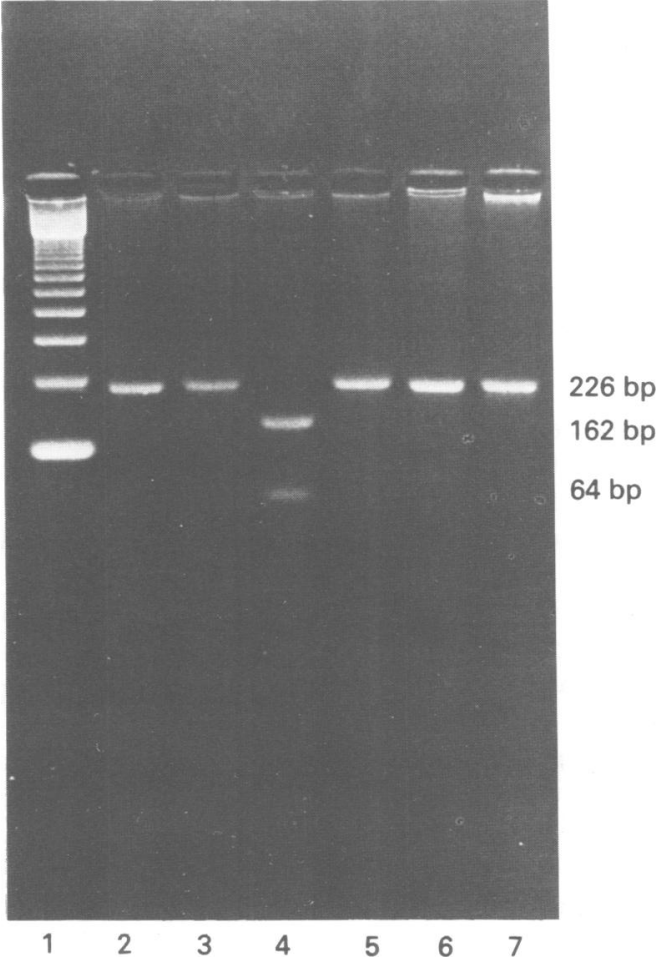

Figure 3 Analysis of the amplified SRY DNA fragments digested with BsmAI on electrophoretic agarose gel. (1) 123 bp DNA ladder marker, (2) father, after BsmAI digestion (226 bp), (3) father, without BsmAI digestion (226 bp), (4)patient, after BsmAI digestion $(162+64 \mathrm{bp})$, (5) patient, without BsmAI digestion (226 bp), (6) normal male, after BsmAI digestion (226 bp), (7) normal male, without BsmAI digestion (226 bp).

the sex determining region of the human $Y$ chromosome, the gene SRY and its mouse equivalent Sry have been cloned. ${ }^{5}$ A number of observations have shown that SRY and mouse Sry have many of the predicted properties of TDF and provide strong evidence for SRY being the TDF. ${ }^{46-8}$ As predicted as a regulatory gene, SRY encodes a protein containing a DNA binding motif. ${ }^{314}$ Recently, it was proven that SRY protein was able to bind to the same core sequence AACAAAG which is recognised by TCF-1. The results suggested that the DNA binding activity of SRY is required for sex determination. ${ }^{15}$

Sex reversal in XY females is caused by failure of the testis determining or differentiation pathways. To date, over 10 mutations have been found in SRY and these mutations, apart from a deletion $5^{\prime}$ to the SRY open reading frame, all lie within the region that encodes the HMG box. ${ }^{6715-20}$ The majority of mutations that have been tested are de novo and are not shared by the fathers of these XY daughters. Recently, SRY sequences derived from six XY females were cloned into a bacterial expression vector. SRY protein was produced from five of the six mutant genes, but the sixth point mutation, a frameshift mutation, was unable to produce SRY protein. When equal amounts of wild type and mutant SRY protein were subjected to electrophoretic mobility shift assays with the SRY oligonucleotide probe, no or reduced DNA binding activity was detected with these point mutations. ${ }^{15}$ SRY mutations encoded by XY females lose this DNA binding activity, which implies that this activity is necessary for testicular development.

In the present paper, we have identified a new point mutation in the SRY gene in a Chinese $X Y$ female, a $G$ to $A$ substitution at codon 113 (A113T) that causes a conservative change from alanine to threonine within the HMG box motif. This mutation leads to complete sex inversion, that is, $\mathrm{XY}$ gonadal dysgenesis, in the patient. Since her father and other family members do not carry the same mutation, it must have occurred de novo. This de novo SRY mutation, together with the data on other mutations in SRY, strongly suggest that SRY mutations are associated with sex reversal syndrome, contributing to our understanding of the molecular basis of XY females.

This work was supported by National Science Grant 863, China. We thank Miss Hai-lan Zhang for preparing the manuscript.

1 McLaren A. Sex determination in mammals. Trends Gene 1988;4:153-7.

2 Goodfellow PN, Darling SM. Genetics of sex determination in man and mouse. Development 1988;102:251-8.

3 Sinclair AH, Berta P, Palmer M, et al. A gene from the human sex-determining region encodes a protein with homology to a conserved DNA-binding motif. Nature 1990;346:240-4.

4 Koopman P, Munsterberg A, Capel B, Vivian N, LovellBadge R. Expression of a candidate sex-determining gene during mouse testis differentiation. Nature 1990;348:450-2.

5 McLaren A. What makes a man a man. Nature 1990;346:216-17.

6 Jager RJ, Anvret M, Hall K, Scherer G. A human XY female with a frame shift mutation in the candidate testisdetermining gene SRY. Nature 1990;348:452-4.

7 Berta P, Hawkins JR, Sinclair AH, et al. Genetic evidence equating SRY and the testis-determining factor. Nature 1990;248:448-50.

8 Koopman P, Gubbay J, Vivian N, Goodfellow P, LovellBadge R. Male development of chromosomally female mice transgenic for Sry. Nature 1991;351:117-21.

9 Saiki RK, Gelfand DH, Stoffel B, et al. Primer-directed enzymatic amplification of DNA with a thermostable DNA polymerase. Science 1988;239:481-97.

10 Huang SZ, Zhou XD, Zhu H, Zeng YT. Diagnosis of hemoglobinopathy by analysis of amplified DNA. Shanghai Med $\mathcal{F} 1988 ; 11: 559-62$.

11 Murray V. Improved double-stranded DNA sequencing using linear polymerase chain reaction. Nucleic Acids Res 1989;17:8889-90.

12 Ford CE, Jones KW. A sex-chromosome anomaly in a case of gonadal dysgenesis (Turner's syndrome). Lancet 1959;i:711-13.

13 Jacobs PA, Strong JA. A case of human intersexuality having a possible XXY sex-determining mechanism. Nature 1959;183:302-3.

14 Gubbay J, Collignon J, Koopman P, et al. A gene mapping to the sex-determining region of the mouse $Y$ chromosome is a member of a novel family of embryonically expressed gene. Nature 1990;346:245-50.

15 Harley VR, Jackson DI, Hextall PJ, et al. DNA binding activity of recombinant SRY from normal males and XY females. Science 1992;255:453-6.

16 Hawkins JR, Taylor A, Berta P, Levilliers, J, Van der Auwera B, Goodfellow PN. Mutational analysis of SRY: nonsense and mutations in XY sex reversal. Hum Genet nonsense and $1992 ; 88: 471-4$.

17 Hawkins JR, Taylor A, Goodfellow PN, Migeon CJ, Smith KD, Berkovitz GD. Evidence for increased prevalence of SRY mutations in XY females with complete rather than partial gonadal dysgenesis. Am $\mathcal{f}$ Hum Genet 1992;51:979-84

18 McElreavey $\mathrm{K}$, Vilain $\mathrm{E}$, Abbas $\mathrm{N}$, et al. XY sex reversa associated with a deletion 5' to the SRY "HMG box" in the testis-determining region. Proc Natl Acad Sci USA 1992;89:11016-20.

19 McElreavey KD, Vilain E, Boucekkine C, et al. XY sex reversal associated with a nonsense mutation in SRY. Genomics 1992;13:838-40.

20 Muller J, Schwartz M, Skakkebaek NE. Analysis of the sexdetermining region of the $\mathrm{Y}$ chromosome (SRY) in sex reversed patients: point-mutation in SRY causing sexreversion in a 46,XY female. $₹$ Clin Endocrinol Metab 1992;75:331-3. 